\title{
Editorial
}

\section{Guest Editorial: Wildfires, Fire Science and Fire Safety Engineering}

\author{
Guillermo Rein*, School of Engineering, University of Edinburgh, \\ Edinburgh, $U K$
}

"A case can be made for fire being, next to the life processes, the most complex of phenomena to understand"

Prof Hoyt Hottel, Massachusetts Institute of Technology, (1903-1998) [1].

This editorial goes to press just as the 2009 Victorian Bushfires Royal Commission (2009 VRC) releases its final report [2]. The Commission conducted an extensive investigation into the causes, preparation for, response to and the impact of the massive wildfires that burned throughout the Australian state of Victoria in late January and early February 2009. The greatest tragedy was that of Black Saturday (7 February) that caused 173 fatalities, exceeding the loss of life from any previous wildfire in the country. The commission estimates the cost of the disaster to be more than US\$3.7 billion ( $€ 2.9$ billion) in terms of property, infrastructure and environmental damages alone. The report is released openly and worldwide to ensure that lessons from the disaster are clearly identified, learnt and shared with the international community.

As one reads the report it is clear that, whilst the scope of both wildfire and fire safety research need to expand, it is also vital that researchers from these two fields better integrate their knowledge and develop closer collaboration if we are to manage the fire problem effectively. Born out of this same necessity, and preceding the 2009 VRC report, this special issue of Fire Technology attempts to bridge the gap between the research of fire science in the built and natural environments.

For this issue we considered 31 original submissions from which 14 were eventually accepted for publication. This task would not have been possible without the effort and motivation of the 75 reviewers who volunteered their time to the issue.

The papers cover a wide range of geographical locations with particular emphasis on Australia, USA, UK, and the Mediterranean countries, and go from the fundamental to the applied sides of the research spectrum. Topics include rapid fire spread and eruptive behaviour (Viegas and Simeoni, invited review), spotting

\footnotetext{
* Correspondence should be addressed to: Guillermo Rein, E-mail: reingu@gmail.com
} 
fires (Wang; Hadden et al. ${ }^{1}$ ), community response to fire and the wild-urban interface (Mutch et al. ${ }^{1}$; Maranghides and Mell), arson behaviour (Beale and Jones) and reformulating fire risk index (Krivtsov and Legg). Given the importance of such topics in current fire science, it is perhaps not entirely coincidental that the 2009 VRC report draws attention to these same issues as research priorities. In this regard as well, a paper reviews the ongoing research efforts on the 2009 Victoria fires (Thornton, invited paper).

Other topics covered here are an overview of computational modelling of wildfires (Morvan, invited review), laboratory-scale tests to study burning fuel behaviour (Madrigal et al.), scaling fire law from the laboratory to the field scales (Perez et al.), using field experiments to measure moisture thresholds for fire spread (Davies and Legg), and novel metrology to study flaming fronts (Rudz et al.).

Another novel topic included here that has gained great relevance since this summer due to the Russian fires burning around Moscow and Siberia is that of smouldering fires of dry peatlands (Moreno et al.).

Throughout this issue it is apparent that fire researchers of the natural and built environments, though often working in different ways, have similar objectives and share core concepts. These fields have a lot to offer one another. Many of the topics treated in this special issue would benefit from further and novel research, and we hope these papers serve as the basis for developing new interdisciplinary collaborations.

\section{References}

1. Hottel HC (1984) Stimulation of fire research in the United States after 1940. Combust Sci Technol 39:1-10. doi:10.1080/00102208408923781

2. Teague B, McLeod R, Pascoe S (2009) 2009 Victorian Bushfires Royal Commission, Final Report, Parliament of Victoria, Australia, ISBN 978-0-9807408-1-3, July 2010. http://www.royalcommission.vic.gov.au/Commission-Reports/Final-Report. Accessed 31 July 2010

\footnotetext{
${ }^{1}$ The papers by Mutch et al. "Protecting Lives and Property in the Wildland-Urban Interface: Communities in California and Montana Adopt Australian Paradigm" and Hadden et al. "Ignition of Combustible Fuel Beds by Hot Particles: an Experimental and Theoretical Study" are the first published in Fire Technology under the new Open Access option offered by Springer.
} 